\title{
Assessment of airborne dust associated with chemical plant: A case study
}

\begin{abstract}
The process of alumina production involves refining of bauxite ore into tri-hydrated alumina $(\mathrm{Al} 2 \mathrm{O} 3,3 \mathrm{H} 2 \mathrm{O})$ by chemical method followed by process of calcinations. This method possesses various kinds of dust hazards in its work environment amongst the people involved. Poor health of industrial employees in India is due to its occupational environment (Park \& Park, 1970), which is a major concern now-a-days. Attempts have been made to recognize the potential sources of airborne dust and to assess the dust load upon exposed workers at different work sites of alumina plants by comparing the observations with the standard values called 'Threshold Limit Values' (T.L.V.) assigned by the international body ACGIH (American Conference of Governmental and Industrial Hygienists), USA, and also permissible exposure limit values prescribed in the second schedule Section F of Factories Act (Amendment), 1987. Alumina plant operation includes various physical operations like crushing, grinding, conveying, loading, transporting, etc., which generate finer particles. It can cause serious health hazards on inhalation, depending upon its size, shape, constituents and duration of exposure. Out of all these parameters, concentration of respirable fraction of airborne dust ( 0.5 to 5.0 micron size) and its free silica content have been reported to cause lung fibrosis as well as occupational disorders. In the present study, attempts have been made to make a survey of respirable fraction of the airborne dust (that remains suspended in air for quite an appreciable time) associated with various operations according to job profiles. It also outlines the probable control measures in order to provide a healthy working environment. Present work aims at identifying and evaluating the degree of workplace dust with special reference to respirable fraction and for recommending suitable suggestive control measures for an effective management of occupational environment.
\end{abstract}

Key words: Pneumoconiosis, respirable dust, threshold limit values (TLV)

\section{INTRODUCTION}

Alumina refinery is a mineral-based chemical plant involving refining of crushed bauxite ore using various chemicals and minerals as input materials like caustic soda, quicklime, coal, wheat bran and mineral acids. (Tables 1, 2 and 3). In the present investigation, dust load upon the concerned has only been considered for study. The alumina plant having production capacity of 10.75 lakh tonnes of calcined alumina per annum with co-generation facility of power plant (Steam generation 200 $\mathrm{T} / \mathrm{hr} \times 4$ and power 18.5 MW x 3) has been taken for field survey.

Exposure to dust causes lung-related diseases called pneumoconiosis. Silicosis is the most common form of pneumoconiosis, which is caused due to occupational exposure of free silica. Table 4, given below, shows the number of people employed in various industries in India with potential risk of exposure to free silica. About 1.7 million workers ${ }^{[6]}$ are engaged in various mineral, mining and steel industries with potential risk of silica exposure.

Since dust is inevitable in mineral industries, the risk factor leading to pneumoconiosis is assessed on the basis of equation: $R=f(d, f, s, i, t)$ Where $\mathrm{R}=$ Health Risk, $\mathrm{d}=$ particle size, $\mathrm{f}=$ concentration of finer dust, $\mathrm{s}$ $=$ specific noxiousness, $\mathrm{t}=$ time of exposure, $\mathrm{i}=$ individual factor (susceptibility).

\section{MATERIALS AND METHODS}

Sampling of respirable fraction of airborne dust for area as well as for personal dose was carried out by Personal Air Samplers (AFC 123, M/s
P. K. Pattajoshi Occupational Health Services, NALCO. Damanjodi-763 008, Orissa, India

For correspondence: P. K. Pattajoshi, Qr No. B-115/Sector-3, Damanjodi-763 008, Koraput, Orissa, India. E-mail:

pkpjoshi@hotmail.com

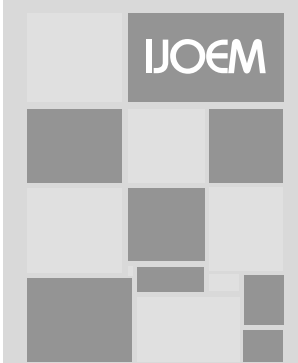


Table 1: Specific consumption of input materials per ton of product

\begin{tabular}{|c|c|}
\hline Input chemicals/raw materials & Consumption pattern \\
\hline Bauxite & $3.0 \mathrm{~T}$ \\
\hline Soda & $67 \mathrm{Kg}(100 \% \mathrm{NaOH})$ \\
\hline Lime & $25 \mathrm{Kg}$ (Available $\mathrm{CaO}: 70 \%)$ \\
\hline Coal & $0.65 \mathrm{~T}$ \\
\hline Wheat bran & $1.0 \mathrm{Kg}$ \\
\hline
\end{tabular}

Casella, UK). Area dust concentration was carried out by fixing the equipment at worksite, and personal dose was assessed by breathing-zone sampling of employee at most of the dust prone operating locations.

Personal dust dose is monitored by using personal air sampler that is fitted with the concerned operator involved in activity and the sampling head loaded with pre-weighed glass fiber filter paper in the specifically designed sampling head at breathing zone of the concerned employee. The air is sucked at a rate of 1.9-2.0 liter/min (l pm) and collected in the sampling head attached with a cyclone separator for size screening into respirable fraction only. The gravimetric mass difference of filter paper over a period of total sampling hour is interpreted on an eight-hour basis sampling on TWA (Total Weighted Average) basis.

\section{RESULTS}

Assessment result of respirable dust exposure (Table 5) revealed that permissible limit values exceeded in locations like lime plant bunker area, bagging plant and wagon tippler of coal handling plant. Depending on the constituent and nature of dust, the probable effect of the hazard can be assessed. However, in the locations recognized as dust-prone area, direct exposure of employees throughout the shift of work is assessed through personal samplings. (Table 6). Out of a total 90 observations, 21 cases have been observed to exceed the limit. From comparison study of respirable dust in area and personal dose of 40 samples, it was observed that personal exposure status for individual dose on TWA basis is less than area concentration, as detailed in Table 7. It may be attributed to less duration of exposure at site or

Table 4: Employees' strength with potential risk of silica exposure

\begin{tabular}{lc}
\hline Name of the Industry & Employment \\
\hline Structural clay products & 222,000 \\
Glass and glass product manufacturing & 67,000 \\
Cement, lime and plaster & 78,000 \\
Mica products & 12,000 \\
Iron and Steel industries & 208,000 \\
Foundries & 284,000 \\
Agate industries & 10,000 \\
Slate pencil industries & 8,000 \\
Coal mines & 550,000 \\
Copper ore mines & 13,000 \\
Chromite mines & 9,000 \\
Gold mines & 12,000 \\
Gypsum mines & 1,000 \\
Iron ore & 49,000 \\
Lime stone mines & 6,000 \\
Magnesite mines & 18,000 \\
Manganese ore mines & 3,000 \\
Mica mines & 11,000 \\
Stone mines & 77,000 \\
\hline
\end{tabular}

Souurce: "Hand Book of Labour Statistics, 1991, Labour bureau, Govt. of India

Table 5: Limit values of various kinds of dust (TWA/8 hours)

\begin{tabular}{lcc}
\hline Type of dust & $\begin{array}{c}\text { Limit value as } \\
\text { per ACGIH }\end{array}$ & $\begin{array}{c}\text { Limit value as per } \\
\text { Factories Act }\end{array}$ \\
\hline Lime dust (Calcium Oxide) & $2.0 \mathrm{mg} / \mathrm{m}^{3}$ & $2.0 \mathrm{mg} / \mathrm{m}^{3}$ \\
Coal dust & $2.0 \mathrm{mg} / \mathrm{m}^{3}$ & $2.0 \mathrm{mg} / \mathrm{m}^{3}$ \\
Nuisances dust (Total) & $10.0 \mathrm{mg} / \mathrm{m}^{3}$ & $10.0 \mathrm{mg} / \mathrm{m}^{3}$ \\
Nuisances dust (Respirable) & $5.0 \mathrm{mg} / \mathrm{m}^{3}$ & $5.0 \mathrm{mg} / \mathrm{m}^{3}$ \\
Respirable dust of & 10 & 10 \\
Silica bearing minerals & $\%$ of Quartz+2 & $\%$ of Quartz+2 \\
\hline
\end{tabular}

Table 2: Recognisation of dust hazards in alumina plant

\begin{tabular}{|c|c|c|}
\hline Location & Job profile & Type of dust \\
\hline Bauxite handling \& Ball mill & Transportation, crushing, stacking conveying, grinding & Bauxite dust \\
\hline Lime Handling & Unloading, screening, conveying, slaking, grit disposal & Lime dust mostly containing $\mathrm{CaO}$ \\
\hline Calcination Plant & Conveying, loading, furnace heating & Alumina dust particles $\left(\mathrm{Al}_{2} \mathrm{O}_{3}\right)$ \\
\hline Coal handling plant & Crsuhing. conveying, pulverising & Coal dust \\
\hline Power plant & Firing, ash disposal and gas emission & Dust of unburnt coal, fly ash etc. \\
\hline
\end{tabular}

Table 3: Typical composition of dust generating materials in alumina plant

\begin{tabular}{|c|c|c|c|c|c|}
\hline & $\mathrm{Al}_{2} \mathrm{O}_{3} \%$ & $\mathrm{Fe}_{2} \mathrm{O}_{3} \%$ & $\mathrm{SiO}_{2} \%$ & LOI\% & Grain size \\
\hline Bauxite Ore & $35-40$ & $20-25$ & $\begin{array}{l}2.0-5.0 \text { (Free silica in air borne } \\
\text { dust is below detection limit) }\end{array}$ & $10-15$ & $\begin{array}{c}<150 \text { micron size:Run of Mines } \\
<63 \text { micron: Feed to ball mill }\end{array}$ \\
\hline Calcined alumina & 98.0 (Min) & 0.001 (Max) & $0.001(\mathrm{Max})$ & 1.0 (Max) & + 125 micron: $15 \%-45$ micron : $12 \%$ \\
\hline Red mud & $10-20$ & $30-60$ & $3.0-20.0$ & $10-15$ & Coarse \\
\hline Lime dust & $2-3 \%$ Total $\mathrm{R}_{2} \mathrm{O}_{3}$ & & & & Coarse \\
\hline Fly ash & $10-15 \%$ & - & $40-50 \%$ in combined form & 1.0 & Coarse/fine \\
\hline
\end{tabular}


Table 6: Assessment of respirable dust in different work areas (TWA basis)

\begin{tabular}{|c|c|c|c|c|c|c|}
\hline \multirow[t]{2}{*}{ Location } & \multirow[t]{2}{*}{ Type of dust } & \multirow[t]{2}{*}{$\begin{array}{l}\text { No. } \\
\text { (n) }\end{array}$} & \multicolumn{2}{|c|}{$\begin{array}{c}\text { Range of observed } \\
\text { value }\left(\mathrm{mg} / \mathrm{m}^{3}\right)\end{array}$} & \multirow[t]{2}{*}{$\begin{array}{l}\text { No. of times } \\
\text { exceeded the limit }\end{array}$} & \multirow[t]{2}{*}{$\begin{array}{l}\text { Prescribed limit } \\
\text { values by ACGIH }\end{array}$} \\
\hline & & & Min. & Max. & & \\
\hline Lime handling plant (loading/unloading) & CaO (Lime dust) & 10 & 2.24 & 3.18 & 4 & 2.0 \\
\hline Slaker of lime handling & Cao (Lime dust) & 10 & 1.12 & 1.154 & Nil & 2.0 \\
\hline Bagging unit of alumina handling & $\mathrm{Al}_{2} \mathrm{O}_{3}$ Alumina dust & 10 & 4.64 & -6.82 & 2 & 5.0 (resp) \\
\hline Loading point alumina handling & $\mathrm{Al}_{2} \mathrm{O}_{3}$ Alumina dust & 10 & 3.28 & 5.69 & 3 & 5.0 (resp) \\
\hline Stacker bauxite handling & Bauxite dust & 10 & 4.14 & 5.48 & 4 & 5.0 (resp) \\
\hline Crushing & Bauxite dust & 10 & 4.34 & 5.34 & 3 & 5.0 (resp) \\
\hline Coal feeding & Coal dust & 10 & 1.12 & 2.14 & 1 & 2.0 \\
\hline Wagon tippler (during coal unloading operation) & Coal dust & 10 & 2.68 & 3.65 & 4 & 2.0 \\
\hline Calcination & $\mathrm{Al}_{2} \mathrm{O}_{3}$ Alumina dust & 10 & 2.24 & 4.02 & 0 & 5.0 \\
\hline
\end{tabular}

Table 7: Comparison of area dust and personal dose sampling for respirable dust (TWA/8 hr basis)

\begin{tabular}{|c|c|c|c|}
\hline Location & $\begin{array}{l}\text { Average concentrationof area sampling } \\
\qquad(n=5) \mathrm{mg} / \mathrm{m}^{3}\end{array}$ & $\begin{array}{l}\text { Average concentration of personal sampling } \\
\qquad(\mathrm{n}=5) \mathrm{mg} / \mathrm{m}^{3}\end{array}$ & Remark \\
\hline Bauxite handling & $4.14(\max 5.14)$ & $3.14(\max 3.64)$ & Area samples exceeds limit \\
\hline Lime handling & $2.04(\max 3.94)$ & $1.32(\max 2.68)$ & values but personal samples \\
\hline Calcination unit & $4.41(\max 5.58)$ & $3.84(\max 4.65)$ & \\
\hline
\end{tabular}

near source continuously for individuals during their $8 \mathrm{~h}$ of work per shift.

\section{DISCUSSION}

From present study, it is concluded that the hazards in all locations are in the proximity of TLV values. The de-dusting systems like bag filter, cyclone, scrubbers, etc., need regular maintenance and also may be kept on line all the time of the operation to reduce dust load. The observed values for respirable dust at locations exceeding TLV can be brought under control of exposure by use of Specific PPEs (Personal Protective Equipment) like suitable nose mask at work site. Adequate ventilation, hooding, good housekeeping, substitution of less harmful substances and other engineering control measures can also reduce the dust load.

\section{REFERENCES}

1. American Conference of Governmental and Industrial Hygienists. $T L V$ and Biological Exposure Indices, ACGIH, USA

2. M.S.Kumar, A.Mahadevan, R.D.Murugesan 'A study on Occupational Environment and the Status of Health in Textile Industry in Madurai, Jr. of Indl.Poll.Control Vol. 5(2) (1989) Pg. 72-79

3. M/S Casella, U.K. Operational Manual for Personal Air Sampler AFC-123, 2000

4. P.B.Pal, Brijmohan,, Management of Occupational Environment in Textile mill, Indian Journal of Environmental Protection Vol 10(10) (1999) Pg 767-772

5. D.K.Ghose. Characterization and Evaluation of Airborne dust associate with Mining operation. Indian Journal of Occupational and Environmental medicine Vol.2 No2 (June 98)

6. DGFASLI, Ministry of Labour, Govt of India. DUST- A Work Environment Pollutant" INDOSHNEWS APR- JUN, (1999 ) Pg 1-5

7. D.Mohanty "Orissa Factory Manual" Cuttack Law House Publications, 2000 